Website: http://journal.umy.ac.id/index.php/mrs

DOI: $10.18196 / \mathrm{jmmr} .6130$

\title{
Pengaruh Komunikasi Terapeutik Perawat Terhadap Kepuasan Pasien di Rawat Jalan RSUD Jogja
}

\author{
Mahendro Prasetyo Kusumo* \\ *Penulis Korespondensi: mahendro@umy.ac.id \\ *Program Manajemen Rumah Sakit Universitas Muhammadiyah Yogyakarta \\ INDEXING \\ Keywords: \\ Therapeutic \\ Communication, \\ Nursing; \\ Patients Satisfaction

\begin{abstract}
A B S T R A C T
The Objective of this study is to know influence of nurse therapeutic communication to satisfaction of patients satisfaction in RSUD Jogja. The study was a quantitative research methods such as surveys of descriptive inferential research with cross sectional approach. Number of samples in this research is 285 sample in inpatient and 140 in emergency room. The instrument used a questionnaire. Analysis of data using multiple linear regression. This study show that there is the influence of therapeutic communication nurse to satisfaction of outpatients and Emergency room in RSUD Jogja, and orientation phase is a phase that most influence on patient satisfaction. The most influential to therapeutic communication is termination stage.
\end{abstract}

Kata kunci:

Komunikasi Terapeutik;

Perawat;

Kepuasan Pasien
Tujuan Penelitian ini adalah untuk mengetahui pengaruh komunikasi terapeutik perawat terhadap kepuasan pasien Poliklinik dan IGD di RSUD Jogja. Jenis penelitian ini adalah penelitian kuantitatif dengan metode penelitan berupa survei deskriptif inferensial dengan pendekatan cross sectional. Jumlah sampel pada penelitian ini berjumlah 285 sampel di poliklinik dan 140 di IGD. Instrumen penelitian yang digunakan adalah kuesioner. Analisis data menggunakan uji regresi linier ganda. Penelitian ini menemukan bahwa terdapat pengaruh komunikasi terapeutik perawat terhadap kepuasan pasien rawat jalan dan IGD di RSUD Jogja, dan tahap orientasi komunikasi terapeutik merupakan tahap yang paling berpengaruh terhadap kepuasan pasien, sedangkan tahap komunikasi terapeutik yang paling berpengaruh di IGD adalah Tahap Terminasi.

(C) 2017 JMMR. All rights reserved

$\overline{\text { Article history: Received } 25}$ Agu 2016; Revised 20 Nov 2016; Accepted 17 Des 2016

\section{PENDAHULUAN}

Dalam praktek keperawatan, komunikasi adalah suatu alat yang penting untuk membina hubungan teraupetik dan dapat mempengaruhi kualitas pelayanan keperawatan. Komunikasi teraupetik menjadi sangat penting karena dapat mempengaruhi tingkat kepuasan pasien terhadap pelayanan kesehatan yang diberikan. Komunikasi terapeutik merupakan komunikasi profesional bagi perawat yang direncanakan dan dilakukan untuk membantu penyembuhan atau pemuliha pasien. Dengan memiliki keterampilan komunikasi terapeutik yang baik, perawat akan lebih mudah menjalin hubungan saling percaya dengan pasien, dan hal ini akan lebih efektif bagi perawat dalam memberikan kepuasan profesional dalam asuhan keperawatan ${ }^{1}$. Di RSUD Kota Jogja kepuasan pasien dipengaruhi oleh banyak faktor, salah satunya komunikasi teraupetik yang dilakukan oleh perawat. Berdasarkan hasil survei awal terhadap pasien di pelayanan medis RSUD Kota Jogja lebih dari 50\% pasien rawat jalan mengatakan kurang puas dengan komunikasi terapeutik yang dilakukan oleh perawat, pasien menyatakan bahwa perawat kurang informatif dan jarang memperkenalkan diri sebelum melakukan perawatan maupun tindakan medis, sedangkan salah satu hal yang mendukung kesembuhan pasien tidak hanya memberikan informasi tentang kesehatannya tapi mendengarkan keluhan pasien, empati, edukasi dan pelayanan yang ramah juga sangat mempengaruhi kesembuhan pasien. Komunikasi terapeutik yang baik akan memberikan kepuasan tersendiri oleh pasien, yang pada akhirnya akan mempengaruhi kepuasan pasien terhadap pelayanan yang diberikan di rumah sakit. Untuk dapat memberikan pelayanan dengan kualitas yang baik maka perlu adanya peningkatan pelayanan di semua bidang secara terpadu, terencana, serta baikseperti komunikasi terapeutik, jika komunikasi terapeutik 
yang diberikan dipelayanan rawat jalan baik maka pasien akan merasakan puas dalam mendapatkan pelayanan di Rumah Sakit, sehingga drajat keembuhan pasien akan meningkat.

\section{METODE PENELITIAN}

Jenis dan rancangan penelitian ini menggunakan survei deskriptif inferensial yaitu penelitian yang mengambil sampel dari suatu populasi dan menggunakan kuesioner sebagai instrument penelitian. Metode yang digunakan dalam penelitian ini dengan pendekatan cross sectional, yaitu jenis survei yang mengamati sebuah objek penelitian, baik satu maupun beberapa variabel, dengan cara menghimpun data pada suatu masa yang sama. Subyek pada penelitian ini, adalah pasien di RSUD kota Jogja, sedangkan objek pada penelitian ini adalah pasien IGD dan Poliklinik di RSUD kota Jogja. Pengambilan sampel pasien poliklinik menggunakan teknik proportionate cluster random sampling. Sedangkan pemilihan sampel pada penelitian ini menggunakan desain simple random sampling. Dalam penelitian ini didapatkan sampel dengan kesalahan $5 \%$ pertiga hari sebanyak 140 sampel IGD dan 285 sampel poliklinik. Penentuan jumlah sampel dari populasi tertentu dengan taraf kesalahan $5 \% \underline{15}$.

\section{Definisi Operasional Variabel}

Variabel Bebas (Independent Variable)

Komunikasi terapeutik adalah komunikasi yang dilakukan oleh tenaga kesehatan dalam memberikan pelayanan kesehatan kepada pasien. Komunikasi yang dinilai dalam penelitian ini adalah komunikasi yang menggunakan tahapan komunikasi teraupetik yang dilakukan perawat di Rawat jalan yaitu: a) Tahapan pre interaksi yang merupakan tahap mengenali kemampuan yang dimiliki sebelum kontak dengan pasien; b) Tahap orientasi merupakan tahap perawat mengenali yang dirasakan oleh pasien; c) Tahap kerja merupakan hal paling utama untuk mencapai suatu tujuan; d) Tahap terminasi merupakan tahap akhir dari pertemuan, tahap ini perawat menciptakan realita perpisahan, mengevaluasi hasil tindakan yang dilakukan dan merencanakan kontak tindak lanjut.

\section{Variabel Tergantung (Dependent Variable)}

Kepuasan pasien adalah perasaan senang dan puas yang dirasakan oleh pasien setelah mendapatkan pelayanan kesehatan di Rawat Jalan RSUD kota Jogja, rasa puas yang dirasakan pasien terjadi ketika pelayanan yang didapatkan sesuai yang diharapkan oleh pasien. Kepuasan pasien dalam penelitian ini akan dinilai dari kuesioner. Penelitian ini menggunakan kuesioner yang disebarkan secara serentak kepada responden yang telah terpilih dan diisi oleh responden pada hari tersebut Kuesioner untuk mengetahui karakteristik responden, seperti umur, alamat, jenis kelamin, status perkawinan, pekerjaan, pendidikan, kelas perawatan, sumber biaya, pihak yang menganjurkan memilih RSUD Kota Jogja Kuesioner untuk mengukur penilaian responden mengenai kepuasan pasien terhadap komunikasi terapeutik yang telah dilaksanakan RSUD Kota Jogja. Instrumen harus memenuhi dua persyaratan penting yaitu valid dan reliabel. Sebuah instrument atau alat ukur dikatakan valid apabila instrument dapat mengukur apa yang seharusnya di ukur $\stackrel{15}{-}$. Pernyataan dikatakan valid bila $r$ hitung lebih besar dari $r$ table dan bila $r$ hitung lebih kecil dari nilai $r$ table maka pertanyaan tersebut tidak valid $^{16}$. Uji reliabilitas ini digunakan untuk mengetahui tingkat kehandalan suatu instrument, sehingga dapat diramalkan apabila alat ukur dipergunakan berkali-kali akan memberikan hasil yang hampir sama dalam waktu yang berbeda dan pada orang yang berbeda ${ }^{16}$. Secara umum reliabilitas dari variable sebuah kuesioner dikatakan cukup baik apabila memiliki koefisien Alpha Cronbach $>0,6 \frac{15}{5}$. Dalam penelitian ini untuk mengetahui karakteristik responden terhadap komunikasi teraupetik terhadap kepuasan pasien di Rawat Jalan dan Instalasi Gawat Darurat RSUD Kota Jogja. Analisis regresi linear ganda merupakan regresi yang digunakan untuk menguji lebih dari satu variabel bebas ${ }^{17}$. Dalam penelitian ini, analisis regresi digunakan untuk menilai pengaruh komunikasi teraupetik perawat terhadap kepuasan pasien di Rawat Jalan dan Instalasi Gawat Darurat RSUD kota Jogja 


\section{HASIL DAN PEMBAHASAN}

\section{Gambaran Umum RSUD Jogja}

RSUD Jogja atau yang terkenal dengan nama Rumah Sakit Jogja merupakan rumah sakit milik pemerintah Kota Yogyakarta yang berada di ujung Selatan Kota Yogyakarta. Berdasarkan SK Menteri Kesehatan RI Nomor HK0203/I/0233/2014 rumah sakit Jogja berubah menjadi rumah sakit tipe $B$ Pendidikan. Dalam 10 tahun belakangan ini rumah sakit berusaha untuk selalu mengembangkan layanan layanan unggulannya. Saat ini Rumah Sakit Jogja sedang mempersiapkan diri menjadi rumah sakit rujukan regional. Kepuasan pasien di rumah sakit jogja sangat dipengaruhi oleh banyak faktor, salah satunya komunikasi teraupetik yang dilakukan oleh perawat. Dari segi pelayanan, rumah saki Jogja memiliki 12 jenis pelayanan yang meliputi: Administrasi dan Manajemen, Pelayanan Medik, Pelayanan Gawat Darurat, Pelayanan Keperawatan, Rekam Medis, Farmasi, Keselamatan Kesehatan Kerja, Radiologi, Laboratorium, Kamar Operasi, Pengendalian infeksi di Rumah Sakit dan Perinatal resiko infeksi.

\section{Hasil Uji Validitas dan Reliabilitas Instrument}

Berdasarkan hasil uji validitas variable komunikasi terapeutik fase orientasi, fase kerja dan fase terminasi menunjukkan bahwa item pertanyaan yang $r$ tabel adalah 0,166 , sedangkan $r$ hitung $>r$ tabel dinyatakan valid atau sig $<0,05$, sehingga semua item pertanyaan dikatakan valid. Sedangkan hasil uji reliabilitas pada tahap orientasi, tahap kerja dan tahap terminasi di RSUD Jogja menunjukkan bahwa seluruh variable mempunyai nilai Alpha Cronbach $>0,06$. Hal ini berarti, pernyataan tersebut reliable sehingga dapat digunakan pada penelitian.

\section{Gambaran Responden Penelitiana}

Responden dalam penelitian ini adalah pasien yang pernah mendapat pelayanan di poliklinik dan IGD RSUD Jogja minimal 1 kali dengan usia diantara 18-55 tahun. Berdasarkan tabel 1, diketahui bahwa dalam pelaksanaan komunikasi terapeutik perawat pada tahap orientasi, kerja dan terminasi di Instalasi Gawat Darurat RSUD Jogja yang terbanyak mengatakan sering dan selalu melakukan komunikasi

Tabel 1. Distribusi Frekuensi Komunikasi Terapeutik pada Tahap Orientasi di Instalasi Gawat Darura

\begin{tabular}{cccc}
\hline Skala Penilaian & $\begin{array}{c}\text { Frekuensi } \\
\text { Orientasi }\end{array}$ & $\begin{array}{c}\text { Frekuensi } \\
\text { Kerja }\end{array}$ & $\begin{array}{c}\text { Frekuensi } \\
\text { Terminaasi }\end{array}$ \\
\hline Tidak Pernah & $3(2.1 \%)$ & $10(7.1 \%)$ & $6(4.3 \%)$ \\
Hampir Tidak Pernah & $14(10 \%)$ & $18(12.9 \%)$ & $24(17.1 \%)$ \\
Ragu-ragu & $30(21.4 \%)$ & $47(33.6 \%)$ & $34(24.3 \%)$ \\
Sering & $57(40.7 \%)$ & $36(25.7 \%)$ & $51(36.4 \%)$ \\
Selalu & $36(25.7 \%)$ & $29(20.7 \%)$ & $25(17.9 \%)$ \\
Total & $140(100 \%)$ & $140(100 \%)$ & $140(100 \%)$ \\
\hline
\end{tabular}

Tabel 2. Distribusi Frekuensi Pelaksanaan Komunikasi Terapeutik pada Tahap Orientasi di Poliklinik RSUD Jogja

\begin{tabular}{cccc}
\hline Skala Penilaian & $\begin{array}{c}\text { Frekuensi } \\
\text { Orientasi }\end{array}$ & $\begin{array}{c}\text { Frekuensi } \\
\text { Kerja }\end{array}$ & $\begin{array}{c}\text { Frekuensi } \\
\text { Terminaasi }\end{array}$ \\
\hline Tidak Pernah & $30(10,5)$ & $23(8,1$ & 16 \\
Hampir Tidak Pernah & $34(11,9)$ & $19(6,7$ & 28 \\
Ragu-ragu & $100(35,1)$ & $79(27,7$ & 57 \\
Sering & $84(29,5)$ & $117(41,1$ & 77 \\
Selalu & $37(13,0)$ & $47(16,5$ & 107 \\
\hline Total & 285 & & 100 \\
\hline
\end{tabular}


Tabel 3. Distribusi Frekuensi Menurut Kepuasan Pasien Pada Tahap Orientasi di Instalasi Gawat Darurat

\begin{tabular}{cccc}
\hline Skala Penilaian & $\begin{array}{c}\text { Frekuensi } \\
\text { Orientasi }\end{array}$ & $\begin{array}{c}\text { Frekuensi } \\
\text { Kerja }\end{array}$ & Frekuensi Terminaasi \\
\hline Sangat Tidak Puas & $4(2.9 \%)$ & $3(2.1 \%)$ & $1(0.7 \%)$ \\
Tidak Puas & $30(21.4 \%)$ & $18(12.9 \%)$ & $17(12.1 \%)$ \\
Ragu-ragu & $44(31.4 \%)$ & $33(23.6 \%)$ & $34(24.3 \%)$ \\
Puas & $47(33.6 \%)$ & $75(53.6 \%)$ & $68(48.8 \%)$ \\
Sangat Puas & $15(10.7 \%)$ & $11(7.9 \%)$ & $20(14.3 \%)$ \\
Total & $140(100 \%)$ & $140(100 \%)$ & $140(100 \%)$ \\
\hline
\end{tabular}

teraupetik adalah pada tahap orientasi yaitu sebanyak 57 sampel dari 140 mengatakan sering.

Tabel 4. Distribusi Frekuensi Kepuasan Pasien pada Tahap Orientasi di Poliklinik RSUD Jogja

\begin{tabular}{cccc}
\hline $\begin{array}{c}\text { Tahap } \\
\text { Orientasi }\end{array}$ & Frekuensi & Frekuensi & Frekuensi \\
\hline $\begin{array}{c}\text { Sangat } \\
\text { tidak puas }\end{array}$ & $9(3,15)$ & $2(0,70)$ & $1(0.4)$ \\
Tidak Puas & $80(28,07)$ & $34(11,92)$ & $27(9.5)$ \\
Ragu- & $42(14,73)$ & $48(16,84)$ & $28(9.8)$ \\
Ragu & & & \\
Puas & $147(51,57)$ & $186(65,26)$ & $208(72)$ \\
Sangat & $7(2,45)$ & $15(5,26)$ & $21(7.4)$ \\
Puas & & & \\
\hline Total & $285(100)$ & $285(100)$ & $285(100)$ \\
\hline
\end{tabular}

Berdasarkan table 2, diketahui bahwa dalam pelaksanaan komunikasi terapeutik perawat pada tahap orientasi, kerja dan terminasi di Poliklinik RSUD Jogja yang terbanyak mengatakan sering dan selalu melakukan komunikasi teraupetik adalah pada tahap orientasi yaitu sebanyak 117 sampel dari 285 mengatakan sering. Berdasarkan table 3, diketahui bahwa dalam pelaksanaan komunikasi terapeutik perawat pada tahap orientasi, kerja dan terminasi di IGD RSUD Jogja yang terbanyak mengatakan sering dan selalu puas dalam melakukan komunikasi teraupetik adalah pada tahap terminasi yaitu sebanyak 88 sampel dari 140 sampel. Berdasarkan table 3, diketahui bahwa dalam pelaksanaan komunikasi terapeutik perawat pada tahap orientasi, kerja dan terminasi di Poliklinik RSUD Jogja yang terbanyak mengatakan sering dan selalu puas dalam melakukan komunikasi teraupetik adalah pada tahap terminasi yaitu sebanyak 229 sampel dari 285 sampel.
Sebelum melakukan analisis data untuk mencari pengaruh antar variabel yang digunakan untuk penelitian, dilakukan uji normalitas dan uji linieritas dengan menggunakan SPSS 16 for Windows. Dapat disimpulkan bahwa semua data yang digunakan memenuhi asumsi normalitas, sehingga syarat regresi terpenuhi. Menurut Prof. H. Imam Ghazali dalam buku “Aplikasi Analisis Multivariate Program IBM spss 19”. Pada penelitian ini peneliti menggunakan test normality Kolmogorov-Smirnov karena jumlah sampel $>50$ sampel, dengan hasil Sig $(0,057)$ dan dapat dikatakan terdistribusi normal karena sig $>0,05$. Oleh karena itu dapat disimpulkan bahwa semua data yang digunakan memenuhi asumsi normalitas, sehingga syarat regresi terpenuhi dan semua variabel penelitian ini linier. Koefisiensi determinasi merupakan suatu alat untuk mengukur besarnya persentase pengaruh variabel bebas terhadap variabel terikat. Biasanya koefisiensi determinasi berkisar antara 0 sampai 1, besar koefisiensi determinasi mendekati angka 1, maka semakin besar pengaruh pelaksanaan komunikasi teraupetik (variable independen) terhadap kepuasan pasien (variabel dependen).

Berdasarkan nilai $\mathrm{R}$ Squared 0.541. Hal ini menunjukkan persentasi pengaruh pelaksanaan komunikasi teraupetik perawat terhadap kepuasan pasien di Instalasi Gawat Darurat RSUD Jogja menunjukkan hasil sebesar 54,1\%, sedangkan Analisis determinasi di poliklinik menunukan hasih sebesar 42.1\%. Sehingga sisanya sebesar $45.9 \%$ dapat dipengaruhi oleh faktor lain seperti faktor biaya, faktor tenaga kerja (jumlah perawat), faktor fasilitas dan mutu informasi. Analisis determinasi dalam regresi linear berganda digunakan untuk mengetahui seberapa besar persentase pelaksanaan komunikasi terauppetik secara bersama-sama terhadap kepuasan pasien 
Uji F statistik pada dasarnya menunjukkan apakah semua variabel indepeden atau bebas yang di masukkan dalam model mempunyai pengaruh secara bersama-sama terhadap variabel dependen/terikat. Dari hasil pengujian di Instalasi Gawat Darurat diperoleh nilai $\mathrm{F}$ hitung 53.540 dan $\mathrm{F}$ tabel sebesar 2.67 dengan nilai signifikasi sebesar 0.000 . Oleh karena F hitung $>$ $\mathrm{F}$ tabel $(53.540>2.67)$ dengan nilai signifikansi lebih kecil dari $0.05(\mathrm{p}<0.05)$, sedangkan di rawa poliklinik didapatkan bahwa nilai $\mathrm{F}$ hitung $>\mathrm{F}$ tabel $(68,125>)$ dengan nilai signifikansi $<0,05(0,000)$ maka hal ini berarti bahwa terdapat Pengaruh Komunikasi Terapeutik Perawat yang signifiikan terhadap Kepuasan Pasien di Instalasi Gawat Darurat RSUD Jogja. Uji ini digunakan untuk mengetahui apakah variabel independen secara bersama-sama berpengaruh secara signifikan terhadap variabel dependen.

Uji $\mathrm{t}$ ini merupakan pengujian untuk menunjukkan pengaruh secara individu variabel bebas yang ada didalam model terhadap variabel terikat. Hal ini dimaksudkan untuk mengetahui seberapa jauh pengaruh variabel satu variabel bebas menjelaskan variasi variabel terikat. Penjelasan hasil uji t di IGD untuk tiap variabel bebas, sebagai berikut:

1) Komunikasi Terapeutik pada Tahap Orientasi Hasil uji t pada tabel 4.15 untuk variabel Komunikasi Terapeutik pada Tahap Orientasi didapat nilai $\mathrm{t}$ hitung sebesar2.449 dan $\mathrm{t}$ tabel $1.977(\mathrm{df}=99, \mathrm{p}=0,05)$ dengan nilai signifikansi 0,016 karena $t$ hitung $>\mathrm{t}$ tabel $(2.449>1.977)$, signifikansi lebih kecil $0.05 \quad(\mathrm{p}<0.05)$ dan koefisiensi regresi mempunyai nilai positif maka dapat disimpulkan bahwa "ada Pengaruh Komunikasi Terapeutik Perawat pada Tahap Orientasi terhadap Kepuasan Pasien di Instalasi Gawat Darurat RSUD Jogja” diterima.

2) Komunikasi Terapeutik pada Tahap Kerja

Hasil uji t pada tabel 4.15 untuk variabel Komunikasi Terapeutik pada Tahap Kerja didapat nilai t hitung sebesar2.607 dan t tabel $1.977(\mathrm{df}=99, \mathrm{p}=0,05)$ dengan nilai signifikansi 0,010 karena $t$ hitung $>\mathrm{t}$ tabel $(2.607>1.977)$, signifikansi lebih kecil $0.05 \quad(\mathrm{p}<0.05)$ dan koefisiensi regresi mempunyai nilai positif maka dapat disimpulkan bahwa "ada Pengaruh Komunikasi Terapeutik Perawat pada Tahap
Kerja terhadap Kepuasan Pasien di Instalasi Gawat Darurat RSUD Jogja” diterima.

3) Komunikasi Terapeutik pada Tahap Terminasi Hasil uji t pada tabel 4.15 untuk variabel Komunikasi Terapeutik pada Tahap Terminasi didapat nilai t hitung sebesar6.465 dan t tabel $1.977(\mathrm{df}=99, \mathrm{p}=0,05)$ dengan nilai signifikansi 0,000 karena $t$ hitung $>\mathrm{t}$ tabel $(6.465>1.977)$, signifikansi lebih kecil $0.05 \quad(\mathrm{p}<0.05)$ dan koefisiensi regresi mempunyai nilai positif maka dapat disimpulkan bahwa "ada Pengaruh Komunikasi Terapeutik Perawat pada Tahap Terminasi terhadap Kepuasan Pasien di Instalasi Gawat Darurat RSUD Jogja” diterima.

Penjelasan hasil uji $\mathrm{t}$ di Poliklinik untuk tiap variabel bebas, sebagai berikut:

1) Komunikasi Terapeutik pada Tahap Orientasi Dapat dilihat pada tabel 4.3 oleh karena nilai $t$ hitung $>\mathrm{t}$ tabel $(5.374>1968)$ dengan nilai signifikansi $<0,05$ dan koefisiensi regresi mempunyai nilai positif pada komunikasi terapeutik tahap orientasi maka Ho di tolak. Artinya ada pengaruh komunikasi terapeutik perawat pada tahap orientasi terhadap kepuasan pasien rawat jalan RSUD Jogja.

2) Komunikasi Terapeutik pada Tahap Kerja Dapat dilihat pada tabel 4.3 oleh karena nilai $t$ hitung $>\mathrm{t}$ tabel (3.945> 1968) dengan nilai signifikansi $<0,05$ dan koefisiensi regresi mempunyai nilai positif pada komunikasi terapeutik tahap kerja maka Ho di tolak. Artinya ada pengaruh komunikasi terapeutik perawat pada tahap kerja terhadap kepuasan ipasien rawat jalan RSUD Jogja.

3) Komunikasi Terapeutikpada Tahap Terminasi Dapat dilihat pada tabel 4.3 oleh karena nilai $t$ hitung $>\mathrm{t}$ tabel $(4.107>1968)$ dengan nilai signifikansi $<0,05$ dan koefisiensi regresi mempunyai nilai positif pada komunikasi terapeutik tahap terminasi maka Ho di tolak. Artinya ada pengaruh komunikasi terapeutik perawat pada tahap terminasi terhadap kepuasan pasien rawat jalan RSUD Jogja.

Dari ketiga tahap komunikasi terapeutik perawat di RSUD jogja didapatkan nilai t hitung yang paling 
besar diantara ketiga tahap tersebut yaitu nilat t hitung pada komunikasi terapeutik tahap orientasi. Artinya tahap komunikasi yang paling berpengaruh terhadap kepuasan pasien di RSUD Jogja yaitu pada tahap orientasi.

\section{Pembahasan}

Bersasarkan dari hasil penelitian dengan menggunakan uji regresi menunjukkan terdapat pengaruh yang signifikan pelaksanaan Komunikasi Terapeutik Perawat terhadap Kepuasan Pasien di Instalasi Gawat Darurat dan Poliklinik RSUD Jogja, hal ini didukung dengan penelitian Sutrisno,dkk yang menyatakan bahwa sebagian besar menyatakan bahwa semakin baik pelaksanaan komunikasi terapeutik yang dilaksanakan maka semakin puas pasien. Hasil penelitian ini sejalan dengan penelitian yang di lakukan oleh Anis (2009) tentang hubungan terapeutik perawat dengan kepuasan pasien dalam pelayanan keperawatan di Rumah Sakit Siti Khodijah di dapatkan data, bahwa dari 39 responden yang terlibat dalam penelitian ini sebagian besar $(84,6 \%)$ menyatakan telah puas dengan pelayanan yang telah diberikan oleh perawat dan sebagainkecil saja atau $15,40 \%$ yang menyatakan kurang puas. Menurut Lambrini, selain dapat meningkatkan kepuasan pasien komunukasi teraupetik yang baik juga akan mempengaruhi hasil pengobatan yang di berikan oleh dokter.

Hasil penelitian menunjukkan Komunikasi Terapeutik Perawat pada Tahap Orientasi, yaitu menurut penilaian responden, Komunikasi Terapeutik yang dilakukan oleh perawat di Instalasi Gawat Darurat RSUD Jogja pada Tahap Orientasi "sering" dilakukan dengan jumlah 57 responden dengan persentase $38,14 \%$ dengan tingkat kepuasan pasien "puas" dengan jumlah 47 responden dengan persentase $33.57 \%$. Menurut Nurhasanah $\frac{18}{-}$ Tahap Orientasi adalah tahap yang dimulai dengan pertemuan dengan pasien dimana bertujuan dalam memvalidasi keakuratan data dan rencana yang telah dibuat sesuai dengan keadaan pasien saat ini. Dalam memulai hubungan, tugas utama adalah membina rasa percaya, penerimaan dan pengertian, komunikasi yang terbuka dan perumusan kontak dengan pasien. Diharapkan pasien berperan serta secara penuh dalam kontrak, namun pada kondisi tertentu, maka kontrak dilakukan sepihak dan perawat perlu mengulang kontrak jika kontak realitas pasien meningkat. Salah satu faktor yang dapat mempengaruhi komunikasi adalah lingkungan. Lingkungan interksi akan mempengaruhi komunikasi yang efektif. Suasana yang bising, tidak ada privasi yang tepat akan menimbulkan kerancuan, ketegangan dan ketidaknyaman ${ }^{-}$. Komunikasi terapeutik pada ruang Instalasi Gawat Darurat berbeda dengan komunikasi yang terjadi dibangsal karena di Instalasi Gawat Darurat lebih memfokuskan pada tindakan yang akan dilakukan sehingga dalam pelaksanaan komunikasi terapeutik sangat kurang. Penanganan kasus gawat darurat memerlukan sebuah sub sistem yang terdiri dari informasi, jaring koordinasi dan jaring pelayanan gawat darurat sehingga seluruh kegiatan dapat berlangsung dalam satu sistem terpadu ${ }^{19}$. Distribusi responden terhadap palaksanaan komunikasi terapeutik perawat di poliklinik pada fase orientasi yang paling tinggi persentasenya adalah 35,1\% "raguragu" karena pada fase orientasi beberapa perawat di poliklinik ada yang melakukan komunikasi terapeutik dan ada yang masih belum melakukan komunikasi terapeutik dalam memberikan pelayanan kesehatan. Sebaiknya pada tahap ini perawat melakukan komunikasi terapeutik dengan baik kepada pasien karena pada tahap inilah penilaian terhadap pelayanan yang di berikan perawat dinilai oleh pasien. hal ini sesuai dengan pendapat ${ }^{20}$ yang menyatakan bahwa fase orientasi merupakan tahap perkenalan antara perawat dengan pasien, dengan memperkenalkan diri kepada pasien berarti perawat telah bersikap terbuka kepada pasien dan memberikan kesan nyaman terhadap pelayanan yang di berikan kepada pasien. Pada tahap orientasi perawat di tuntut untuk memiliki keahlian untuk menstimulasi pasien dan keluarga untuk dapat mengungkapkan keluhannya ${ }^{4}$. Dengan komunikasi terapeutik yang baik pada tahap orientasi maka perawat akan lebih mudah dalam menggali keluhankeluhan pasien.

Hasil penelitian menunjukkan Komunikasi Terapeutik Perawat pada Tahap Kerja, yaitu menurut penilaian responden, komunikasi terapeutik yang dilakukan oleh perawat di Instalasi Gawat Darurat RSUD Jogja pada Tahap Kerja "ragu-ragu" dilakukan dengan jumlah 47 responden dengan persentase $33.57 \%$ tingkat kepuasan pasien "puas" dengan jumlah 75 responden dengan persentase $53.57 \%$. Tahap kerja merupakan inti dari hubungan perawat dan pasien yang terkait erat dengan pelaksanaan rencana tindakan keperawatan yang akan dilaksanakan sesuai 
dengan tujuan yang dicapai. Meningkatkan interaksi sosial dengan cara meningkatkan sikap penerimaan satu sama lain untuk mengatasi kecemasan, atau dengan menggunakan teknik komunikasi terapeutik sebagai cara pemecahan dan dalam mengembangkan hubungan kerja sama. Tahap kerja merupakan tahap yang terpanjang dalam komunikasi terapeutik karena didalamnya perawat dituntut untuk membantu dan mendukung pasien untuk menyampaikan perasaan dan pikirannya dan kemudian menganalisa respon ataupun pesan komunikasi verbal dan non verbal yang disampaikan oleh pasien. Dalam tahap ini perawat mendengarkan secara aktif dan dengan penuh perhatian sehingga mampu membantu pasien untuk mendefiniskan masalah yang sedang dihadapi oleh pasien, mencari penyelesaian masalah dan mengevaluasinya ${ }^{18}$. Tahap kerja dalam komunikasi terapeutik merupakan tahap dimana perawat memberikan kesempatan kepada pasien untuk bertanya, menanyakan keluhan pasien, memulai segala tindakan dengan baik dan melakukan tindakan sesuai dengan yang telah di sepakati ${ }^{21}$. Hasil penelitian komunikasi pada tahap kerja terdapat 117 responden dengan persentas $41,1 \%$ yang menyatakan bahwa perawat di rawat jalan RSUD Jogja sering melakukan komunikasi terapeutik tahap kerja kepada pasien saat memberikan pelayanan di rawat jalan.

Hasil penelitian menunjukkan Komunikasi Terapeutik Perawat pada Tahap Terminasi, yaitu menurut penilaian responden, Komunikasi Terapeutik yang dilakukan oleh perawat di Instalasi Gawat Darurat RSUD Jogja pada Tahap Terminasi memilih "sering" dengan jumlah 51 responden dengan persentase $36.43 \%$ dengan tingkat kepuasan pasien "puas" dengan jumlah 68 responden dengan persentase 48.57\%. Tahap Terminasi merupakan tahap dimana perawat mendorong pasien untuk memberikan penilaian atas tujuan yang telah dicapai, agar tujuan yang dicapai adalah kondisi yang menguntungkan dan memuaskan ${ }^{5}$. Hasil penelitian menunjukkan bahwa Tahap Terminasi merupakan tahap yang paling sering dilakukan perawat dan berpengaruh dalam kepuasan pasien di Instalasi Gawat Darurat RSUD Jogja, hal ini didukung oleh penelitian 22 , Tahap Terminasi mendapatkan kategori yang baik dalam pelaksanaan komunikasi terapeutik oleh perawat. Instalasi Gawat Darurat merupakan tempat akan sering ditemukan kasus kegawatan yang harus segera mendapat pelayanan dan perawatlah yang selalu kontak pertama dengan pasien 24 jam. Oleh sebab itu, pelayanan professional harus ditingkatkan karena pasien gawat darurat mebutuhkan pelayanan yang cepat, tepat dan cermat dengan tujuan mendapatkan kesembuhan tanpa cacat. Oleh karenanya perawat Instalasi Gawat Darurat disamping mendapat bekal ilmu pengetahuan keperawatan juga perlu untuk lebih meningkatkan keterampilan yang spesifik seperti tambahan pengetahuan penanggulangan penderita gawat darurat ${ }^{5}$. Menurut Pohan ${ }^{23}$ kepuasan pasien adalah suatu tingkat perasaan yang timbul sebagai akibat dari kinerja pelayanan kesehatan yang diperoleh setelah pasien mebandingkan dengan apa yang diharapkan. Perawat dalam memberikan asuhan keperawatan tidak terlepas dari sikap dan perilaku dalam berkomunikasi dengan pasien yang dapat mempengaruhi kepuasan pasien, meskipun sarana dan prasarana pelayanan sering dijadikan ukuran mutu oleh pelanggan namun $\backslash$ ukuran utama penilaian tetap sikap dan perilaku pelayanan yang ditampilkan oleh petugas.Sikap dan perilaku yang baik oleh perawat sering dapat menutupi kekurangan dalam hal sarana dan prasarana. Komunikasi yang dilakukan perawat dalam menyampaikan informasi sangat berpengaruh terhadap kepuasan pasien. Hasil penelitian didapatkan, bahwa ada hubungan antara komunikasi terapeutik perawat dengan kepuasan pasien.Perawat merupakan kunci yang dapat mempengaruhi kepuasan pasien, hal ini disebabkan karena seringnya interaksi antara perawat dan pasien selama menjalani masa perawatan.Salah satu hal yang dilakukan perawat dalam menjaga kerjasama yang baik dengan pasien dalam membantu memenuhi kebutuhan kesehatan pasien, maupun dengan tenaga kesehatan lain dalam rangka membantu mengatasi masalah pasien adalah dengan berkomunikasi. Dengan berkomunikasi perawat dapat mendengar perasaan pasien dan menjelaskan prosedur tindakan keparawatan 12 . Komunikasi terapeutik perawat pada tahap terminasi di rawat jalan RSUD Jogja didapatkan 107 responden dengan persentase $37,5 \%$ menyatakan "selalu", artinya dalam memberikan pelayanan kesehatan di rawat jalan RSUD Jogja perawat selalu menerapkan komunikasi terapeutik pada tahap terminasi. Tahap terminasi ini merupakan tahap yang paling sulit dan penting, karena hubungan saling percaya sudah terbina dan berada pada tingkat optimal, tahap terminasi dapat terjadi 
pada saat perawat mengakhiri tugas pada unit tertentu atau saat klien akan pulang ${ }^{24}$. Pada saat tahap terminasi inilah perawat dan pasien bersama-sama meninjau kembali proses pelayanan kesehatan yang telah di lalui. Perawat diharapkan dapat mengevaluasi pencapaian tujuan interaksi yang telah dilakukan dengan menanyakan perasaan klien setelah berinteraksi atau setelah melakukan tindakan tertentu serta membuat kontrak untuk pertemuan berikutnya. Pada saat tahap terminasi inilah perawat dan pasien bersama-sama meninjau kembali proses pelayanan kesehatan yang telah di lalui. Perawat diharapkan dapat mengevaluasi pencapaian tujuan interaksi yang telah dilakukan dengan menanyakan perasaan klien setelah berinteraksi atau setelah melakukan tindakan tertentu serta membuat kontrak untuk pertemuan berikutnya.

Dari gambaran hasil keseluruhan tentang komunikasi terapeutik perawat di rawat jalan RSUD Jogja, responden merasa puas dengan komunikasi terapeutik perawat baik itu tahap orientasi, tahap kerja maupun tahap terminasi. Komunikasi terapeutik yang di aplikasikan secara baik akan memberikan kenyamanan tersendiri kepada pasien sehingga membuat pasien merasa puas atas pelayanan yang diberikan terutama dalam hal komunikasi terapeutik. Hal ini sejalan dengan pernyataan ${ }^{25}$ bahwa pasien hanya akan merasa puas apabila kinerja layanan kesehatan yang diperolehnya sama atau melebihi dari yang diharapkan. Menurut Meyana ${ }^{26}$ kepuasan pasien terhadap komunikasi yang di lakukan oleh perawat merupakan tingkat perasaan pasien setelah membandingkan komunikasi perawat yang dirasakan dengan yang diinginkan oleh pasien setelah mendapatkan pelayanan kesehatan. Salah saatu indikasi kepuasan konsumen terhadap pelayanan kesehatan yang ada di rumah sakit adalah kepuasan terhadap komunikasi yang dilakukan oleh tenaga kesehatan, khususnya perawat ${ }^{27}$. Dalam penelitian ini pasien merasa puas dengan komunikasi terapeutik yang di lakukan perawat di rawat jalan RSUD Jogja.

Kepuasan pasien terhadap komunikasi terapeutik perawat di rawat jalan RSUD Jogja di nilai degan melakukan uji analisis regresi, pada tahap orientasi di dapatkan nilai $\mathrm{t}$ hitung $>\mathrm{t}$ tabel disertai nilai signifikansi sebesar $0,000 \quad(<0,05)$ sehingga dapat dikatakan bahwa ada pengaruh komunikasi terapeutik perawat pada tahap orientasi terhadap kepuasan pasien. Pada tahap kerja di dapatkan nilai thitung $>\mathrm{t}$ tabel di sertai nilai signifikansi $0,000(<0,05)$ sehingga dapat dikatakan bahwa ada pengaruh komunikasi terapeutik perawat pada tahap kerja terhadap kepuasan pasien. Untuk tahap terminasi didapatkan hasil analisis nilai t hitung $>$ nilai $\mathrm{t}$ tabel disertai dengan nilai signifikansi $0,000 \quad(<0,05)$ sehingga dapat dikatakan bahwa ada pengaruh komunikasi terapeutik perawat pada tahap terminasi terhadap kepuasan pasien rawat jalan RSUD Jogja. Sedangkan tahap komunikasi terapeutik yang paling berpengaruh terhadap kepuasan pasien dapat di lihat dari nilai $\mathrm{t}$ hitung yang paling tinggi di antara ketiga tahap komunikasi yang telah di uji, nilai t hitung yang paling tinggi yaitu nilai t hitung pada tahap orientasi yaitu sebesar 5,374 sehingga dapat dikatakan bahwa komunikasi terapeutik tahap orientasilah yang paling berpengaruh terhadap kepuasan pasien rawat jalan RSUD Jogja. Hasil penelitian ini di dukung oleh penelitian yang pernah dilakukan oleh $\mathrm{Aswad}^{28}$ denga judul hubungan komunikasi terapeutik perawat dengan kepuasan pasien di instalasi gawat darurat rsud dr. $\mathrm{H}$. Chasan boesoirie ternate.

\section{SIMPULAN}

Berdasarkan hasil penelitian dan pembahasan yang telah dilakukan, maka dapat ditarik kesimpulan penelitian sebagai berikut :Terdapat Pengaruh Pelaksanaan Komunikasi Terapeutik Perawat pada Tahap Orientasi, Tahap Kerja dfan Tahap Terminasi terhadap Kepuasan Pasien di Instalasi Gawat Darurat dan Poliklinik RSUD Jogja.Tahap Pelaksanaan Komunikasi Terapeutik Perawat yang paling mempengaruhi terhadap Kepuasan Pasien di Instalasi Gawat Darurat RSUD Jogja adalah Tahap Terminasi, sedangkan Komunikasi Terapeutik Perawat yang paling mempengaruhi terhadap Kepuasan Pasien di Instalasi Gawat Darurat RSUD Jogja adalah Tahap Orientasi.

Berdasarkan kesimpulan penelitian, maka saran yang dapat diberikan adalah sebagai berikut :Bagi pihak manajemen rumah sakit memberlakukan kebijakan tentang komunikasi terapeutik yang dimasukkan dalam poin penilaian kinerja dan Monitoring dan evaluasi setiap perawat tentang komunikasi terapeutik perawat. Sedangkan bagi 
peneliti selanjutnya diharapkan dapat melakukan penelitian lanjutan mengenai hubungan komunikasi terapeutik terhadap kepuasan pasien dengan meneliti faktor lain dari komunikasi terapeutik yang dapat memberikan pengaruh besar terhadap kepuasan pasien, dan juga dapat melakukan penelitian tentang komunikasi terapeutik, dapat menggunakan desain penelitian yang menggabungkan antara penelitian kuantitatif dan kualitatif (mix method) atau metode observasi, agar peneliti dapat mendapatkan hasil penelitian yang objektif.

\section{DAFTAR PUSTAKA}

1. Damayanti, Mukhripah, 2008. Komunikasi teraupetik dalam praktik keperawatan. PT Refika Aditama, Bandung.

2. Afnuhazi,Ridhyalla 2014. Komunikasi terapeutik dalam keperawatan jiwa. Gosyen Publishing, Jakarta.

3. Nasir A,Abdul M, Sajidin, Wahit Iqbal, 2009, Komunikasi dalam Keperawatan Teori dan Aplikasi. Salemba Medika, Jakarta.

4. Nasir, M, 2013, Hubungan Komunikasi Terapeutik Perawat Terhadap Tingkat Kepuasan Pasien dan Keluarga Di Instalasi Gawat Darurat Rumah Sakit PKU Muhammadiyah Yogyakarta. Journal Ilmiah. Universitas Muhammadiyah Yogyakarta.

5. Khotimah Marsito \& Iswati N, 2012,'Hubungan komunikasi terapeutik perawat dengan kepuasan pelayanan keperawatan diruang Inayah Rumah Sakit PKU Muhammadiyah Gombong',Jurnal Ilmiah Kesehatan Keperawatan, Vol 8, no 2, juni, 2012

6. Fanada M, 2012. Pelaksanaan perawat dalam melakukan komunikasi terapeutik pada pasien waham di Rumah Sakit Ernaldi Bahar Palembang 2012.Jurnal keperawatan.

7. Keputusan Menteri Kesehatan Nomor 1239/MenKes/SK/XI/2001 Tentang Registrasi dan Praktek Perawat, Jakarta

8. Departemen Kesehatan, 2010. Profil Kesehatan Indonesia Tahun 2010, Jakarta : Dirjen Yanmed.

9. Fandy Tjiptono,2006. Manajemen Jasa. Edisi Pertama. Yogyakarta : Andi
10. Potter and Perry, 2006, Buku ajar fundamental keperawatan konsep, proses dan praktek, vol 1,edk 4. EGC, Jakarta.

11. Hanafi I \& Richard S.D, 2012,'Keterampilan komunikasi interpersonal perawat berpengaruh peningkatan kepuasan pasien, Journal Keperawatan Vol 5, no 2.http://www.download.portalgaruda.org/article.p hp?articleDiakses 29 januari 2016

12. Liang \& Tang, 2013, 'The chinese community patient's life statisfication, assesment of community medical service and trust in Community health delivery system health and quality of life outcomes.Health Journal.nih.gov.China

13. Wijono D, 2008, Manajemen mutu rumah sakit dan kepuasan pasien. Duta Prima Airlangga, Surabaya.

14. Sugiyono, 2015, Metode penelitian manajemen.Alfabeta, Bandung.

15. Arikunto S, 2006, Prosedur Penelitian Suatu Pendekatan Praktik, Edisi Revisi VI, Rineka Cipta, Jakarta.

16. Martono, Nanang, 2011. Metode Kuantitatif. Edisi revisi.Jakarta : Rajagrafindo.

17. Nurhasanah, nunung, 2011, Ilmu Komunikasi Dalam Kontes Keperawatan Untuk Mahasiswa Keperawatan. CV.Trans Info Media, Jakarta.

18. PUSBANKES 118, 2012. Komunikasi di Ruang Instalasi Gawat Darurat. Jakarta : EGC.

19. Suryani. 2015. Komunikasi Terapeutik Teori \& Praktik, Ed 2, ECG, Jakarta

20. Mundakir, 2006, Komunikasi keperawatan aplikasi dalam pelayanan. Edisi pertama, EGC, Jakarta

21. Yulita, Ari, 2015, Hubungan Komunikasi Terapeutik Perawat Terhadap Tingkat Kepuasan Pasien Rawat Inap dibangsal Kelas III RSUD Wates Kulon Progo, Journal Ilmiah, Universitas Muhammadiyah Yogyakarta

22. Pohan, I.S. 2007. Jaminan Mutu Layanan Kesehatan. Penerbit Buku Kedokteran, Jakarta.

23. Lalongkoe, R. 2013. Komunikasi keperawatan, Graha Ilmu, Yogyakarta.

24. Wahyudin, Uud. (2009). Membangun Komunikasi Terapeutik. (Internet). 29 Januari 2009 Available from: (www.m.kompas.com) (Accessed 18 Oktober 2010) 
25. Meyana, Fakhirah. 2009. Hubungan Sikap Perawat dengan Tingkat Kepuasan Pasien Rawat Inap di PKU Muhammadiya Yogyakarta. Journal Ilmiah. Stikes Aisyah.Yogyakarta

26. Suryani. 2015. Komunikasi Terapeutik Teori \& Praktik, Ed 2, ECG, Jakarta.

27. Aswad, S., Mulyadi., Lolong, J. 2015. Hubungan komunikasi terapeutik perawat dengan kepuasan pasien di instalasi gawat darurat RSUD DR.H Chasan Boesoirie Ternate, Vol 3, no 2.Di akses 14 Agustus 2016. 